\title{
METODA PENGHILANGAN ZAT BESI DAN MANGAN DI DALAM PENYEDIAAN AIR MINUM DOMESTIK
}

\author{
Oleh : \\ Nusa Idaman Said \\ Kelompok Teknologi Pengelolaan Air bersih dan Limbah Cair, Pusat Pengkajian dan Penerapan \\ Teknologi Lingkungan, BPPT.
}

\begin{abstract}
Small amounts of iron and manganese are quite common in domestic water supply because of the presence of iron and manganese in the soil and rock formations through which the water passes in reaching the point of use. Iron and manganese is characterized by red-brown staining of bathroom fixtures and laundry, and cause taste and odor problems. Iron and manganese are brought into solution by biological reactions under anaerobic reducing conditions. When the water is exposed to air or oxygen, oxidation of iron and manganese occurs slowly, forming objectionable colloidal precipitates. The deposition of these precipitates will stain plumbing fixtures, interfere with laundering, and cause difficulties in water distribution systems by supporting growth of microorganisms such as clonotrix and crenotrix that can clog pipelines and cause taste and odor problems. Processes in which oxidation is followed by removal of suspended solids can effectively remove soluble iron and manganese from water. Three common processes for removing iron and manganese are: aeration-filtration, chlorination filtration, and potassium permanganate-manganese greensand filtration. This article describes these processes and present result from pilot's studies of iron and manganese removal from water.
\end{abstract}

Kata kunci : zat besi, mangan, aerasi, kkhlorinasi, filtrasi, mangan zeolit.

\section{PENDAHULUAN}

\subsection{Masalah Zat Besi dan Mangan Di dalam Air Minum}

Keberadaan zat besi dan mangan di dalam sistem penyediaan air minum domestik telah menjadi masalah yang serius sejak lama. Zat besi dan mangan yang terlarut di dalam air umumnya berada dalam keadaan bervalensi dua (divalent) atau dalam keadaan ion ferous atau ion manganous. Keduanya juga sering berada dalam keadaan senyawa dengan zat organik kompleks. Zat besi atau mangan yang berada dalam keadaan senyawa dengtan zat organik kompleks umumnya lebih sulit untuk dioksidasi dibanding dengan zat besi atau mangan yang bersenyawa dengan zat organik biasa.

Besi atau mangan masuk ke dalam air oleh karena reaksi biologis pada kondisi reduksi atau anaerobik (tanpa oksigen). Jika air yang mengandung besi atau mangan dibiarkan terkena udara atau oksigen maka reaksi oksidasi besi atau mangan akan timbul dengan lambat membentuk endapan atau gumpalan koloid dari oksida besi atau oksida mangan yang tidak diharapkan. Endapan koloid ini akan menempel atau tertinggal dalam sistem perpipaan, menyebabkan noda pada cucian pakaian, serta dapat menyebabkan masalah pada sistem pipa distribusi disebabkan karena dapat menyokong tumbuhnya mikroorganisme seperti crenothrix dan clonothrix yang dapat menyumbat perpipaan serta dapat menimbulkan warna serta bau yang tidak enak. Pada konsentrasi rendah zat besi dan mangan dapat menimbulkan rasa atau bau logam pada air minum, oleh karena itu untuk air minum kadar zat besi dan mangan yang diperbolehkan yakni masing-masing $0,3 \mathrm{mg} / \mathrm{l}$ dan 0,05 mg/l (Standar US EPA).

\subsection{Senyawa Besi di dalam Air}

Besi seperti juga cobalt dan nikel di dalam susunan berkala unsur termasuk logam golongan VII , dengan berat atom 55,85, berat jenis 7,86 , dan mempunyai titik lebur $2450^{\circ} \mathrm{C}$. Di alam biasanya banyak terdapat di dalam bijih besi hematite, magnetite, limonite dan pyrite (FeS), sedangkan di dalam air umumnya dalam bentuk senyawa garam ferri atau garam ferro (valensi 2). Senyawa ferro dalam air yang sering dijumpai adalah $\mathrm{FeO}, \mathrm{FeSO}_{4}, \mathrm{FeSO}_{4} .7 \mathrm{H}_{2} \mathrm{O}, \mathrm{Fe}$ $\mathrm{CO}_{3}, \mathrm{Fe}(\mathrm{OH})_{2}, \mathrm{FeCl}_{2}$ dan lainnya, sedangkan senyawa ferri yang sering dijumpai yakni $\mathrm{FePO}_{4}$, $\mathrm{Fe}_{3} \mathrm{O}_{3}, \mathrm{FeCl}_{3}, \mathrm{Fe}(\mathrm{OH})_{3}$ dan lainnya. (Tatsumi, 1971)

Untuk air minum, konsentrasi zat besi dibatasi maksimum $0,3 \mathrm{mg} / \mathrm{l}$. Hal ini ditetapkan bukan ditetapkan berdasarkan alasan kesehatan semata tetapi ditetapkan berdasarkan alasan masalah warna, rasa, serta timbulnya kerak yang 
menempel pada sistem perpipaan atau alasan estetika lainnya. Manusia dan mahluk hidup lainnya dalam kadar tertentu memerlukan zat besi sebagai nutrient, tetapi untuk kadar yang berlebihan perlu dihindari. Untuk garam ferro misalnya ferrosulfat $\left(\mathrm{FeSO}_{4}\right)$ dengan konsentrasi 0,1-0,2 mg/l dapat menimbulkan rasa yang tidak enak pada air minum. Dengan dasar ini standar air minum WHO untuk Eropa menetapkan kadar besi di dalam air minum maksimum $0,1 \mathrm{mg} / \mathrm{l}$.

Berbeda dengan mangan, zat besi di dalam air minum pada tingkat konsentrasi $\mathrm{mg} / \mathrm{l}$ tidak memberikan pengaruh yang buruk pada kesehatan, tetapi dalam kadar yang besar dapat menyebabkan air menjadi berwarna coklat kemerahan yang tidak diharapkan. Oleh karena itu di dalam proses pengolahan air minum, garam besi valensi dua (ferro) yang larut di dalam air perlu dirubah menjadi garam besi valensi tiga (feri) yang tak larut di dalam air sehingga mudah dipisahkan. Untuk itu perlu proses oksidasi dengan cara aerasi atau dengan zat oksidator. Untuk air permukaan biasanya kandungan zat besi relatif rendah yakni jarang melebihi $1 \mathrm{mg} / \mathrm{l}$, tetapi untuk air tanah kandungan zat besinya sangat bervariasi dari konsentrasi yang rendah sampai konsentrasi yang tinggi $(1-10 \mathrm{mg} / \mathrm{l})$.

\subsection{Senyawa Mangan di dalam Air}

Mangan (Mn) merupakan unsur logam golongan VII, dengan berat atom 54,93, titik lebur $1247^{\circ} \mathrm{C}$, dan titik didihnya $2032{ }^{\circ} \mathrm{C}$. Di alam jarang sekali berada dalam keadaan unsur. Umumnya berada dalam keadaan senyawa dengan berbagai macam valensi. Di dalam hubungannya dengan kualitas air yang sering dijumpai adalah senyawa mangan dengan valensi 2, valensi 4 dan valensi 6. (Tatsumi, 1971)

Di dalam sistem air alami dan juga di dalam sistem pengolahan air, senyawa mangan dan juga besi berubah-ubah tergantung derajat keasaman $(\mathrm{pH})$ air. Perubahan senyawa besi dan mangan di alam berdasarkan kondisi $\mathrm{pH}$ secara garis besar dapat ditunjukkan seperti pada Gambar 1.

Di dalam gambar tersebut dapat dilihat bahwa di dalam sistem air alami pada kondisi reduksi, mangan dan juga besi pada umumnya mempunyai valensi dua yang larut di dalam air. Oleh karena itu di dalam sistem pengolahan air senyawa mangan dan besi valensi dua tersebut dengan berbagai cara oksidasi diubah menjadi senyawa yang mempunyai valensi yang lebih tinggi yang tak larut di dalam air sehingga dapat dengan mudah dipisahkan secara fisik. Walaupun $\mathrm{Mn}$ di dalam senyawa senyawa $\mathrm{MnCO}_{3}, \mathrm{Mn}(\mathrm{OH})_{2}$ mempunyai valensi dua, zat tersebut relatif sulit larut di dalam air, tetapi untuk senyawa $\mathrm{Mn}$ seperti garam $\mathrm{MnCl}_{2}, \mathrm{MnSO}_{4}$, $\mathrm{Mn}\left(\mathrm{NO}_{3}\right)_{2}$ mempunyai kelarutan yang besar di dalam air.

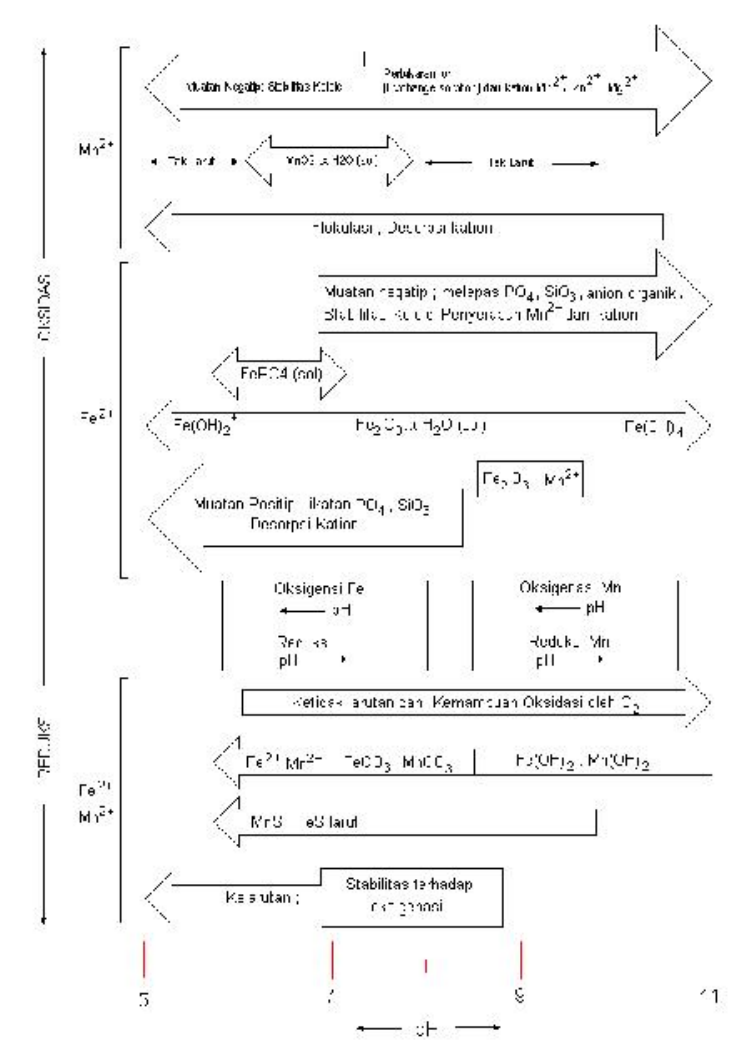

Gambar 1 : Keberadaan zat besi atau mangan di dalam lingkungan air alami.

(Disesuaikan dari Tatsumi Iwao, 1971)

Konsentrasi mangan di dalam sistem air alami umumnya kurang dari $0,1 \mathrm{mg} / \mathrm{l}$, jika konsentrasinya melebihi $1 \mathrm{mg} / \mathrm{l}$ maka dengan cara pengolahan biasa sangat sulit untuk menurunkan konsentrasinya sampai derajat yang diijinkan sebagai air minum. Oleh karena itu perlu cara pengolahan yang khusus. WHO untuk Eropa pada tahun 1961 menetapkan standar konsentrasi Mangan di dalam air minum maksimum $0,1 \mathrm{mg} / \mathrm{l}$, tetapi selanjutnya diperbarui menjadi $0,05 \mathrm{mg} / \mathrm{l}$. Untuk Amerika Serikat sejak awal menetapkan konsentrasi Mangan di dalam air minum maksimum 0,05 mg/l. Jepang menetapkan total konsentrasi besi dan mangan di dalam air minum maksinum $0,3 \mathrm{mg} / \mathrm{l}$. UntuK Indonesia berdasarkan Keputusan Menteri Kesehatan Republik Indonesia Nomor 907/MENKES/SK/VII/2002 menetapkan kadar zat besi di dalam air minum yang diperbolehkan maksinum $0,3 \mathrm{mg} / \mathrm{l}$ dan kadar mangan maksimum yang diperbolehkan $0,1 \mathrm{mg} / \mathrm{l}$.

Standar WHO, Amerika dan Jepang seperti tersebut di atas tidak semata-mata 
ditetapkan berdasarkan sudut pandang kesehatan tetapi juga ditetapkan berdasarkan kenyataan bahwa besi dan mangan di dalam air dapat menimbulkan bau dan rasa yang tidak sedap serta air yang berwarna hitam (black water).

Di dalam tubuh manusia, mangan dalam jumlah yang kecil tidak menimbulkan gangguan kesehatan, tetapi dalam jumlah yang besar dapat tertimbun di dalam hati dan ginjal. Ada berbagai pendapat tentang gangguan kesehatan akibat keracunan senyawa mangan, tetapi umumnya dalam keadaan kronis menimbulkan gangguan pada sistem saraf dan menampakkan gejala seperti penyakit parkinson. Berdasarkan percobaan yang dilakukan terhadap kelinci, keracunan mangan menimbulkan gangguan pada pertumbuhan tulang.

\section{METODA PENGHILANGAN ZAT BESI DAN MANGAN DI DALAM AIR MINUM}

Masalah zat besi dan mangan di dalam air minum lebih sering terjadi jika sumber air baku yang digunakan berasal dari air tanah. Untuk air permukaan masalah zat besi atau mangan umumnya terjadi jika sumber air yang digunakan berasal dari danau yang kedalamannya cukup tinggi (dalam) atau danau yang telah mengalami eutropikasi dimana terjadi kondisi reduksi atau anaerobik di bagian bawah atau dasar danau. Kondisi tersebut dapat mengakibatkan terlarutnya kembali endapan senyawa oksida besi atau mangan yang ada di dasar danau atau reservoir tersebut. Sering juga masalah seperti ini terjadi secara musiman atau pada perioda tertentu saja.

Jika sumber air yang digunakan untuk penyediaan air minum mengandung konsentrasi zat besi lebih besar 0,3 $\mathrm{mg} / \mathrm{l}$ atau kandungan mangan melebihi $0,05 \mathrm{mg} / \mathrm{l}$ maka perlu pemilihan cara pengolahan yang paling sesuai.

Untuk menghilangkan zat besi atau mangan di dalam air yang paling sering digunakan adalah dengan cara oksidasi yang diikuti proses pemisahan padatan (suspended solids). Mangan lebih sulit dioksidasi dari pada besi. Hal ini disebabkan karena kecepatan oksidasi mangan lebih rendah dibanding dengan kecepatan oksidasi besi.

Ada beberapa cara oksidasi besi atau mangan yang paling sering digunakan di dalam industri pengolahan air minum antara lain yakni proses aerasi-filtrasi, proses khlorinasi-filtrasi dan proses oksidasi kalium permanganat-Filtrasi dengan mangan zeolit (manganese greensand) (Wong, 1984).

Pemilihan proses tersebut dipilih berdasarkan besarnya konsentrasi zat besi atau mangan serta kondisi air baku yang digunakan.
Proses lain seperti pertukaran ion, proses filtrasi dengan penambahan chlorine dioxide, proses pengaturan $\mathrm{pH}$, proses filtrasi dengan katalis dengan media yang sesuai serta proses oksidasi dengan ozone jarang digunakan karena alasan biaya dan operasional. Rekomendasi untuk proses tersebut dapat ditemukan di dalam berbagai literatur tentang pengolahan air.

Proses aerasi-filtrasi umumnya lebih dianjurkan untuk pengolahan air dengan konsentrasi zat besi lebih besar $5 \mathrm{mg} / \mathrm{l}$ untuk menghemat biaya bahan kimia. Proses khlorinasi - filtrasi lebih disarankan untuk konsentrasi zat besi kurang dari $2 \mathrm{mg} / \mathrm{l}$, sedangkan proses filtrasi dengan manganese greensand dengan penambahan kalium permanganat direkomendasikan untuk penghilangan zat besi dengan konsentrasi 0-3 mg/l.

\subsection{Proses Aerasi-Filtrasi}

Proses aerasi-filtrasi biasanya terdiri dari aerator, bak pengendap serta filter atau penyaring. Aerator adalah alat untuk mengontakkan oksigen dari udara dengan air agar zat besi atau mangan yang ada di dalam air baku bereaksi dengan oksigen membentuk senyawa ferri (Fe valensi 3) serta mangan oksida yang relatif tidak larut di dalam air. Kecepatan oksidasi besi atau mangan dipengaruhi oleh $\mathrm{pH}$ air. Umunnya makin tinggi $\mathrm{pH}$ air kecepatan reaksi oksidasinya makin cepat. Kadang-kadang perlu waktu tinggal sampai beberapa jam setelah proses aerasi agar reaksi berjalan tergantung dari karakteristik air bakunya.

Jika konsentrsi zat besi atau mangan di dalam air baku cukup tinggi maka perlu bak pengendap yang dilengkapi dengan pengumpul lumpur (sludge collection). Untuk unit fitrasi lebih disarankan menggunakan filter bertekanan dengan dua media yakni pasir silika dan anthrasite. Kelemahan yang utama dari proses aerasi-filtrasi iini adalah besarnya biaya awal untuk pembuatan unit peralatan. Di samping itu jika konsentrasi mangan lebih besar $1 \mathrm{mg} / \mathrm{l}$ maka reaksi oksidasi cukup lama sehingga perlu waktu tinggal yang lebih lama atau kadang memerlukan tambahan bahan kimia untuk mempercepat proses oksidasi mangan tersebut sampai tingkat konsentarsi yang diharapkan.

Di dalam proses penghilangan besi dan mangan dengan cara Aerasi, adanya kandungan alkalinity, (HCO3)- yang cukup besar dalam air, akan menyebabkan senyawa besi atau mangan berada dalam bentuk senyawa ferro bikarbonat, $\mathrm{Fe}\left(\mathrm{HCO}_{3}\right)_{2}$ atau mangano bikarbonat, $\mathrm{Mn}\left(\mathrm{HCO}_{3}\right)_{2}$. Oleh karena bentuk $\mathrm{CO}_{2}$ bebas lebih stabil daripada (HCO3) ${ }^{-}$, maka senyawa 
bikarbonat cenderung berubah menjadi senyawa karbonat.

$\mathrm{Fe}(\mathrm{HCO} 3)_{2}===>\mathrm{FeCO}_{3}+\mathrm{CO}_{2}+\mathrm{H}_{2} \mathrm{O}$
$\mathrm{Mn}(\mathrm{HCO} 3)_{2}===>\mathrm{MnCO}_{3}+\mathrm{CO}_{2}+\mathrm{H}_{2} \mathrm{O}$

Dari reaksi tersebut dapat dilihat, jika $\mathrm{CO}_{2}$ berkurang, maka kesetimbangan reaksi akan bergeser ke kanan dan selanjutnya reaksi akan menjadi sebagai berikut :

$\mathrm{FeCO}_{3}+\mathrm{CO}_{2}===>\mathrm{Fe}(\mathrm{OH})_{2}+\mathrm{CO}_{2}$

$\mathrm{MnCO}_{3}+\mathrm{CO}_{2}===>\mathrm{Mn}(\mathrm{OH})_{2}+\mathrm{CO}_{2}$

Baik hidroksida besi (valensi 2) maupun hidroksida mangan (valensi 2) masih mempunyai kelarutan yang cukup besar, sehingga jika terus dilakukan oksidasi dengan udara atau aerasi akan terjadi reaksi (ion) sebagai berikut :

$$
\begin{aligned}
& 4 \mathrm{Fe}^{2+}+\mathrm{O}_{2}+10 \mathrm{H}_{2} \mathrm{O}===>4 \mathrm{Fe}(\mathrm{OH})_{3}+8 \mathrm{H}^{+} \\
& 2 \mathrm{Mn}^{2+}+\mathrm{O}_{2}+2 \mathrm{H}_{2} \mathrm{O}===>2 \mathrm{MnO}_{2}+4 \mathrm{H}^{+}
\end{aligned}
$$

Sesuai dengan reaksi tersebut, maka untuk mengoksidasi setiap $1 \mathrm{mg} / \mathrm{l}$ zat besi dibutuhkan $0,14 \mathrm{mg} / \mathrm{l}$ oksigen dan setiap $1 \mathrm{mg} / \mathrm{l}$ mangan dibutuhkan $0,29 \mathrm{mg} / \mathrm{l}$. Pada $\mathrm{pH}$ rendah, kecepatan reaksi oksidasi besi dengan oksigen (udara) relatif lambat, sehingga pada prakteknya untuk mempercepat reaksi dilakukan dengan cara menaikkan $\mathrm{pH}$ air yang akan diolah. Pengaruh $\mathrm{pH}$ terhadap oksidasi besi dengan udara (aerasi) dapat dilihat pada Tabel 1 dan Gambar 2.

Tabel 1 : Pengaruh pH terhadap oksidasi besi dengan udara.

\begin{tabular}{|c|c|c|c|c|}
\hline \multicolumn{2}{|c|}{ Air Baku } & \multicolumn{3}{|c|}{ Konsentrasi Fe setelah aerasi } \\
\hline $\mathrm{pH}$ Air & Fe $(\mathrm{ppm})$ & 15 menit & 30 menit & 60 menit \\
\hline 5,0 & 10,0 & 9,0 & - & 7,5 \\
5,5 & 10,0 & 5,5 & 4,6 & 4,0 \\
5,95 & 10,0 & 5,0 & 4,0 & 3,5 \\
6,15 & 10,0 & 4,4 & 3,5 & 2,5 \\
6,5 & 10,0 & 2,8 & 1,8 & 0,3 \\
6,65 & 10,0 & 0,7 & 0,2 & 0,1 \\
6,8 & 10,0 & 0,2 & 0,1 & $<0,1$ \\
7,0 & 10,0 & 0,1 & $<0,1$ & $<0,1$ \\
7,45 & 10,0 & 0,1 & $<0,1$ & $<0,1$ \\
8,05 & 10,0 & $<0,1$ & $<0,1$ & $<0,1$ \\
\hline
\end{tabular}

Catatan : Air baku yang digunakan adalah air tanah. Konsentrasi Fe setelah diaerasi dan disaring dengan kertas saring.

Sumber : Tatsumi Iwao, 1971.

Ada beberapa jenis peralatan aerasi yang sering digunakan yakni aerator gravitasi, aerator sembur (spray aerator), aerator dengan difuser, dan aerator secara mekanik (Benefiled, 1982; Fair and Geyer, 1971; Peavy, 1986; Hammer, 1986).
Untuk aerator gravitasi, beberapa cara yang sering digunakan misalnya aerator baki (tray aerator), aerator cascade, aerator dengan tower vertikal misalnya bubble cap tray dan lainnya.

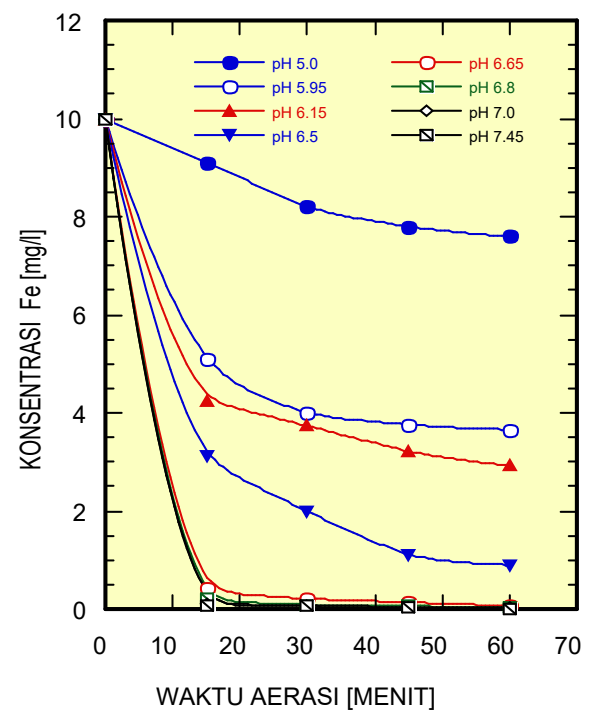

Gambar 2: Pengaruh $\mathrm{pH}$ terhadap oksidasi besi dengan udara.

Catatan : Air baku yang digunakan adalah air tanah. Konsentrasi Fe setelah diaerasi dan disaring dengan kertas saring. Sumber: Tatsumi Iwao, 1971.

Untuk aerator sembur (spray aerator) cara yang sering digunakan adalah aerator dengan menggunakan nozzle atau orifice, baik yang stationer maupun bergerak.

Untuk aerator dengan difuser dilakukan dengan cara menyemburkan udara bertekanan ke dalam air melalui difuser yang berbentuk nozzle, pipa berlubang, atau difuser gelembung halus. Dengan cara demikian maka akan terjadi kontak yang efektif antara oksigen atau udara dengan zat besi atau mangan yang ada di dalam air sehingga terjadi reaksi oksidasi zat besi atau mangan membentuk oksida yang tak larut dalam air. Untuk aerator mekanik, beberapa cara yang sering digunakan adalah submerged paddle, surface paddle, propeler blade atau turbine blade.

Beberapa contoh peralatan aerasi yang sering digunakan yakni :

\section{a. Aerator Baki (Tray Aerator)}

Susunannya sangat sederhana dan tidak mahal serta memerlukan ruangan yang relatif kecil. Jenis aerator ini terdiri atas 4 sampai 8 tray dengan susunan vertikal maupun piramida. Dasar tray berlubang-lubang dengan jarak 30-50 $\mathrm{cm}$. Melalui pipa berlubang air dibagi merata melalui tray, dari bagian ini percikan air turun dengan kecepatan $0,02 \mathrm{~m}^{3} /$ detik per $\mathrm{m}^{2}$ 
permukaan tray. Tetesan air yang menyebar dikumpulkan kembali pada setiap permukaan tray berikutnya. Tray dapat terbuat dari semen sabes (asbestos cement), PVC, logam maupun kayu. Untuk mendapatkan penyebaran air yang lebih halus, tray dapat diisi dengan kerikil kasar dengan ketebalan $\pm 10 \mathrm{~cm}$, kadang-kadang digunakan lapisan batu apung atau arang sebagai katalisator dan mempercepat proses penggumpalan besi dalam air.

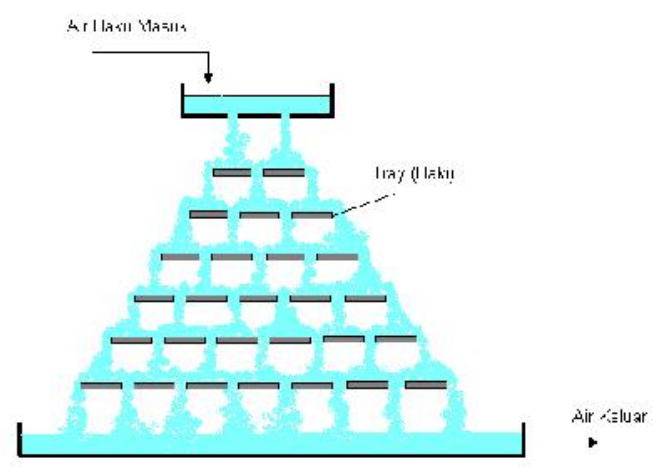

Gambar 3 : Aerator Baki (Tray Aerator)

\section{b. Cascade Aerator}

Pada dasarnya aerator ini terdiri atas 4 sampai 6 step, dengan ketinggian tiap step $\pm 30 \mathrm{~cm}$ dengan kecepatan $0,01 \mathrm{~m}^{3} /$ detik per $\mathrm{m}^{2}$. Dibandingkan dengan jenis tray, aerator jenis cascade ini tempat yang dibutuhkan lebih besar namun total kehilangan tekanan lebih rendah dan keuntungan lain tidak memerlukan pemeliharaan

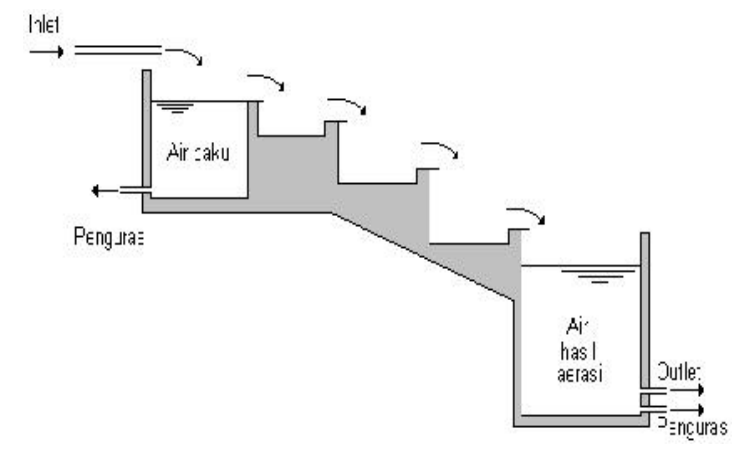

Gambar 4. Cascade aerator

\section{c. Submerged Cascade Aerator}

Submerged Cascade Aerator atau aerasi tangga meluncur penangkapan udara terjadi pada saat air terjun dari lempengan-lempengan trap yang membawanya masuk ke dalam air yang dikumpulkan kelempengan di bawahnya. Total ketinggian jatuh $\pm 1,5 \mathrm{~m}$ yang dibagi dalam $3-5$ step. Kapasitas peralatan ini antara 0,005 sampai $0,5 \mathrm{~m}^{3} /$ detik per $\mathrm{m}^{2}$.

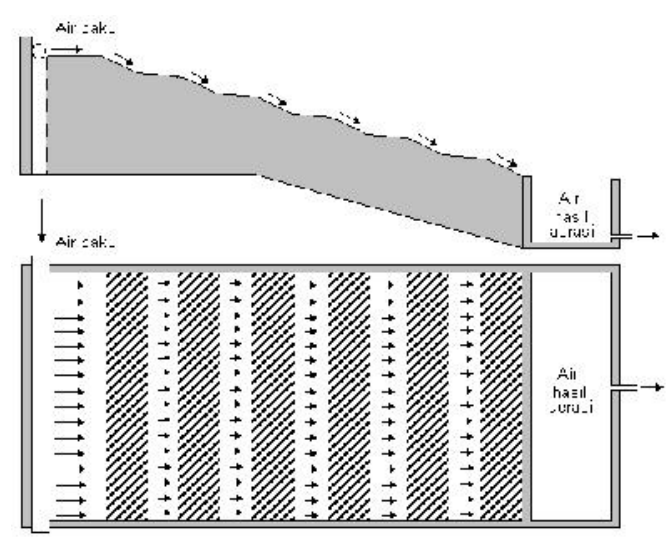

Gambar 5 : Submerged Cascade Aerator

\section{d. Spray Aerator}

Terdiri atas nozel penyemprotan statis (stationary nozzles), dihubungkan dengan kisi lempengan yang mana air disemprotkan ke udara di sekeliling pada kecepatan 5-7 m/detik. Aliran pada spray aerator dari arah bawah melalui pipa yang panjangnya $\pm 25 \mathrm{~cm}$ dan diameter $15-30 \mathrm{~mm}$. Piringan melingkar ditempatkan beberapa centimeter di setiap ujung pipa, sehingga dapat terbentuk selaput air tipis melingkar yang selanjutnya menyebar menjadi percikan air yang halus
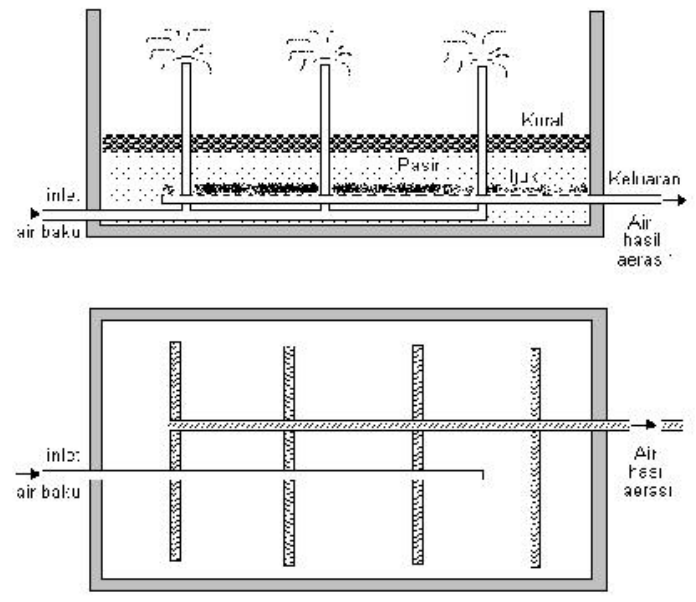

Gambar 6 : Aerator sembur (Spray aerator).

\section{e. Aerator Dengan Difuser Gelembung (Bubble aerator)}

Jumlah udara yang dibutuhkan untuk bubble aerator tidak banyak, yaitu sekitar 0,3-0,5 $\mathrm{m}^{3}$ Udara per $\mathrm{m}^{3}$ air dan volume ini dengan sangat mudah untuk ditingkatkan. Udara dialirkan melalui perpipaan yang diletakkan pada dasar bak. 


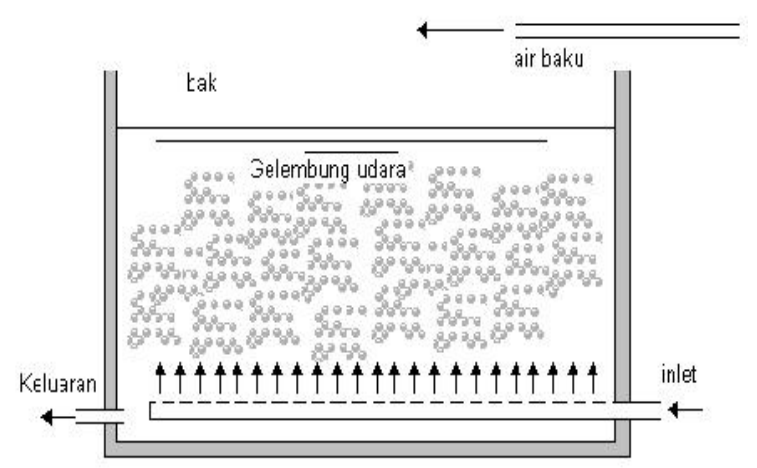

Gambar 7 : Bubble aerator

\subsection{Proses Khlorinasi-Filtrasi}

Di dalam proses Khlorinasi - Filtrasi unit peralatan yang digunakan relatif sederhana. Umumnya terdiri dari sistem pembubuhan (injeksi) bahan kimia dan beberapa unit filter. Unit filter yang digunakan di dalam proses ini sama dengan filter yang digunakan pada AerasiFiltrasi. Kadang-kadang perlu tangki retensi kecil serta pengaturan $\mathrm{pH}$ dengan penambahan soda ash, soda api atau kapur tohor $\left(\mathrm{Ca}(\mathrm{OH})_{2}\right)$. Bahan kimia yang digunakan adalah gas khlorine atau hipokhlorit.

Gas khlorine $\left(\mathrm{Cl}_{2}\right)$ dan ion hipokhlorit $(\mathrm{OCl})^{-}$adalah merupakan bahan oksidator yang kuat sehingga meskipun pada kondisi $\mathrm{pH}$ rendah dan oksigen terlarut sedikit, dapat mengoksidasi dengan cepat. Reaksi oksidasi antara besi dan mangan dengan khlorine adalah sebagai berikut

$$
\begin{aligned}
2 \mathrm{Fe}^{2+}+\mathrm{Cl}_{2}+6 \mathrm{H}_{2} \mathrm{O}==> & 2 \mathrm{Fe}(\mathrm{OH})_{3}(\mathrm{~s})+2 \mathrm{Cl}^{-}+ \\
& 6 \mathrm{H}^{+} \\
\mathrm{Mn}^{2+}+\mathrm{Cl}_{2}+2 \mathrm{H}_{2} \mathrm{O}==> & \mathrm{MnO}_{2}(\mathrm{~s})+2 \mathrm{Cl}^{-}+4 \mathrm{H}^{+}
\end{aligned}
$$

Berdasarkan reaksi tersebut di atas, maka untuk mengoksidasi setiap $1 \mathrm{mg} / \mathrm{l}$ zat besi dibutuhkan 0,64 mg/l khlorine dan setiap $1 \mathrm{mg} / \mathrm{l}$ mangan dibutuhkan $1,29 \mathrm{mg} / \mathrm{l}$ khlorine. Tetapi pada prakteknya, pemakaian khlorine ini lebih besar dari kebutuhan teoritis karena adanya reaksi-reaksi samping yang mengikutinya. Disamping itu apabila kandungan besi dalam air baku jumlahnya besar, maka jumlah khlorine yang diperlukan dan endapan yang terjadi juga besar sehingga beban flokulator, bak pengendap dan filter menjadi besar pula.

Berdasarkan sifatnya, pada tekanan atmosfir khlorine adalah berupa gas. Oleh karena itu, untuk mengefisienkannya, khlorine disimpan dalam bentuk cair dalam suatu tabung silinder bertekanan 5 sampai 10 atmosfir. Untuk melakukan khlorinasi, khlorine dilarutkan dalam air kemudian dimasukkan ke dalam air yang jumlahnya diatur melalui orifice flowmeter atau dosimeter yang disebut khlorinator. Pemakaian kaporit atau kalsium hipokhlorit untuk mengoksidasi atau menghilangkan besi dan mangan relatif sangat mudah karena kaporit berupa serbuk atau tablet yang mudah larut dalam air. Oksidasi Fe dengan khlorine dapat dilakukan dengan efektif walaupun pada kondisi $\mathrm{pH}$ rendah. Salah satu hasil penelitian oksidasi Fe dengan khlorine pada $\mathrm{pH}$ rendah ditunjukkan pada Tabel 2.

Tabel 2 : Oksidasi senyawa $\mathrm{Fe}\left(\mathrm{Fe}^{+2}\right)$ dengan khlorine pada $\mathrm{pH}$ rendah

\begin{tabular}{|c|c|c|c|c|}
\hline \multicolumn{2}{|c|}{ Air Baku } & \multicolumn{3}{c|}{ Konsentrasi Fe setelah Oksidasi dg } \\
$\mathrm{Cl}_{2}$ \\
\hline pH Air & Fe (ppm) & 15 menit & 30 menit & 60 menit \\
\hline 4 & 10,0 & - & - & 0,8 \\
4,55 & 10,0 & - & - & 0,5 \\
5,0 & 10,0 & $<0,1$ & $<0,1$ & $<0,1$ \\
\hline
\end{tabular}

Catatan : Air baku yang digunakan adalah air tanah. Konsentrasi Fe setelah diaerasi dan disaring dengan kertas saring.

Sumber: Tatsumi Iwao, 1971.

\subsection{Proses Kalium Permangganat - Filtrasi dengan Manganese Greensand (mangan zeolit)}

Untuk menghilangkan besi dan mangan dalam air, dapat pula dilakukan dengan mengoksidasinya dengan memakai oksidator kalium permanganat dengan persamaan reaksi sebagai berikut :

$$
\begin{aligned}
3 \mathrm{Fe}^{2+}+\mathrm{KMnO}_{4}+7 \mathrm{H}_{2} \mathrm{O}==> & 3 \mathrm{Fe}(\mathrm{OH})_{3}+\mathrm{MnO}_{2} \\
& +\mathrm{K}^{+}+5 \mathrm{H}^{+} \\
3 \mathrm{Mn}^{2+}+2 \mathrm{KMnO}_{4}+2 \mathrm{H}_{2} \mathrm{O}== & 5 \mathrm{MnO}_{2}+2 \mathrm{~K}^{+} \\
+ & 4 \mathrm{H}^{+}
\end{aligned}
$$

Secara stokhiometri, untuk mengoksidasi $1 \mathrm{mg} / \mathrm{l}$ besi diperlukan $0,94 \mathrm{mg} / \mathrm{l}$ kalium permanganat dan untuk $1 \mathrm{mg} / \mathrm{l}$ mangan diperlukan 1,92 mg/l kalium permanganat. Dalam prakteknya, kebutuhan kalium permanganat ternyata lebih sedikit dari kebutuhan yang dihitung berdasarkan stokhiometri. Hal ini disebabkan karena terbentuknya mangan dioksida yang berlebihan yang dapat berfungsi sebagai oksidator dan reaksi berlanjut sebagai berikut :

$$
\begin{aligned}
2 \mathrm{Fe}^{2+}+2 \mathrm{MnO}_{2}+5 \mathrm{H}_{2} \mathrm{O}==> & 2 \mathrm{Fe}(\mathrm{OH})_{3}+ \\
& \mathrm{Mn}_{2} \mathrm{O}_{3}+4 \mathrm{H}^{+} \\
3 \mathrm{Mn}^{2+}+\mathrm{MnO}_{2}+4 \mathrm{H}_{2} \mathrm{O}==> & 2 \mathrm{Mn}_{2} \mathrm{O}_{3}+8 \mathrm{H}^{+}
\end{aligned}
$$

Peralatan yang digunakan di dalam proses ini sama dengan peralatan pada proses khlorinasi - Fliltrasi, yang berbeda adalah bahan kimia oksidator yang digunakan yakni kalium 
permanganat dan media filter yang digunakan yakni manganese greensand (mangan zeolit). Larutan kalium permanganat 1-4\% secara kontinyu diinjeksikan ke dalam air baku sebelum proses filtrasi. Injeksi larutan kalium permanganat tersebut biasanya dilakukan dengan menggunakan pompa dosing yang dapat diatur laju pembubuhannya. Biasanya reaksi oksidasi dapat berjalan sempurna pada $\mathrm{pH}$ 7,5 9,0 .

Mangan zeolit (manganese-treated greensand) adalah mineral yang dapat menukar elektron sehingga dapat mengoksidasi besi ataiu mangan yang larut di dalam air menjadi bentuk yang tak larut sehingga dapat dipisahkan dengan filtrasi. Mangan Zeolit ( $\left.\mathrm{K}_{2} \mathrm{Z} . \mathrm{MnO} \cdot \mathrm{Mn}_{2} \mathrm{O}_{7}\right)$ dapat juga berfungsi sebagai katalis dan pada waktu yang bersamaan besi dan mangan yang ada dalam air teroksidasi menjadi bentuk ferri-oksida dan mangandioksida yang tak larut dalam air. Reaksinya adalah sebagai berikut:

$$
\begin{gathered}
\mathrm{K}_{2} \mathrm{Z} \cdot \mathrm{MnO} \cdot \mathrm{Mn}_{2} \mathrm{O}_{7}+4 \mathrm{Fe}\left(\mathrm{HCO}_{3}\right)_{2}==>\mathrm{K}_{2} \mathrm{Z}+ \\
3 \mathrm{MnO}_{2}+2 \mathrm{Fe}_{2} \mathrm{O}_{3}+8 \mathrm{CO}_{2}+4 \mathrm{H}_{2} \mathrm{O} \\
\mathrm{K}_{2} \mathrm{Z} \cdot \mathrm{MnO} \cdot \mathrm{Mn}_{2} \mathrm{O}_{7}+2 \mathrm{Mn}\left(\mathrm{HCO}_{3}\right)_{2}==>\mathrm{K}_{2} \mathrm{Z}+ \\
5 \mathrm{MnO}_{2}+4 \mathrm{CO}_{2}+2 \mathrm{H}_{2} \mathrm{O}
\end{gathered}
$$

Reaksi penghilangan besi dan mangan dengan mangan zeolite tidak sama dengan proses pertukaran ion, tetapi merupakan reaksi dari $\mathrm{Fe}^{2+}$ dan $\mathrm{Mn}^{2+}$ dengan oksida mangan tinggi (higher mangan oxide).

Filtrat yang terjadi mengandung mengandung ferri-oksida dan mangan-dioksida yang tak larut dalam air dan dapat dipisahkan dengan pengendapan dan penyaringan. Selama proses berlangsung kemampuan reaksinya makin lama makin berkurang dan akhirnya menjadi jenuh. Untuk regenerasinya dapat dilakukan dengan menambahkan larutan kalium permanganat kedalam mangan zeolite yang telah jenuh tersebut sehingga akan terbentuk lagi mangan zeolite $\left(\mathrm{K}_{2} \mathrm{Z} . \mathrm{MnO} \cdot \mathrm{Mn}_{2} \mathrm{O}_{7}\right)$.

Keunggulan proses ini adalah mangan zeolit dapat berlaku sebagai buffer (penyangga). Jika penambahan kalium permanganat tidak dapat mengoksidasi zat besi atau mangan yang larut di dalam air secara sempurna maka mangan zeolit akan mengoksidasi logam-logam tersebut dan tersaring di dalamnya.

\section{PILOT PLANT STUDI}

\subsection{Pilot Plant untuk menghilangkan zat besi dan mangan skala rumah tangga dengan Proses Aerasi - Filtrasi}

Unit peralatan terdiri dari pompa air baku, bak penampung yang berfungsi sebagai kontaktor udara atau oksigen dengan air, dan satu unit filter yang diisi dengan media pasir, mangan zeolit dan karbon aktif (filter multi media). Air tanah dipompa ke bak penampung yang berfungsi untuk mengontakkan oksigen dari udara dengan zat besi atau mangan yang larut di dalam air. Kemudian dari tangki penampung, air dialirkan ke unit filter multi media untuk menyaring atau menghilangkan zat besi atau mangan yang ada dalam air serta menghilangkan padatan tersuspensi.

Jika ingin mendapatkan hasil yang lebih jernih, proses dapat dilengkapi dengan filter cartridge. Filter cartridge ini dapat menghilangkan padatan tersuspensit dengan ukuran lebih besar 5 (lima) mikron. Dari filter cartridge air olahan sudah sangat jernih, dan apabila diinginkan dapat langsung diminum, air dari filter cartridge dialirkan ke sterilisator ultra violet untuk mematikan atau membunuh mikroorganisme patogen yang ada dalam air. Proses ini tanpa memerlukan energi yang besar karena bekerja dengan sistem gravitasi dan hanya memerlukan energi listrik sekitar 30 watt untuk lampu disinfeksi ultra violetnya. Air yang keluar dari sterilisator UV sudah dapat diminum langsung. Skema proses pengolahan ditunjukkan pada Gambar 8.

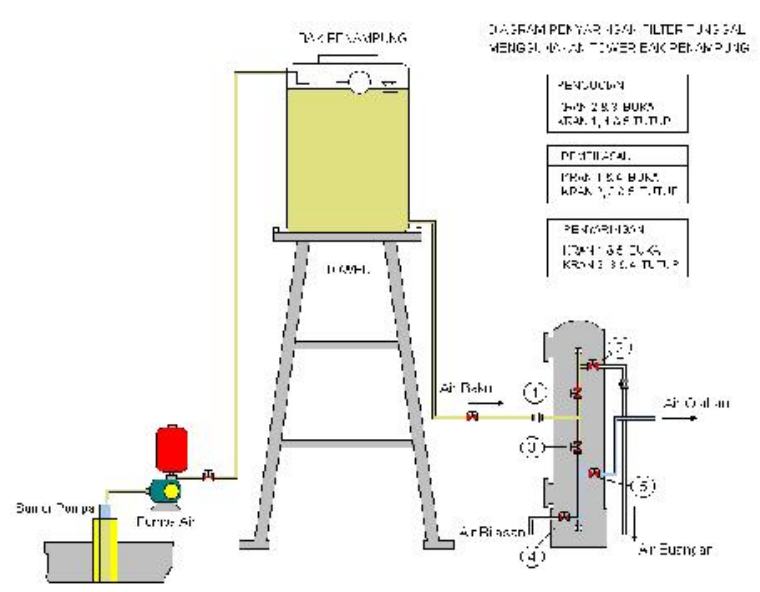

Gambar 8 : Diagram proses penghilangan zat besi dan mangan skala rumah tangga dengan proses aerasi-filtrasi.

Pada saat air dipompa ke bak penampung, terjadi proses oksidasi antara zat besi atau mangan yang ada dalam air dengan oksigen yang ada di udara. Reaksi oksidasi tersebut menghasilkan senyawa ferrihidroksida atau mangan dioksida yang berupa gumpalan sangat halus (micro flock) yang tak larut dalam air, sehinggga dapat tersaring pada filter multi media. Berdasarkan reaksi tersebut diatas, untuk mengoksidasi setiap $1 \mathrm{mg} / \mathrm{l}$ zat besi memerlukan 0,14 mg/l oksigen, dan untuk setiap I mg/l mangan diperlukan oksigen sebanyak 0,29 mg/l . 
Dengan memompa air baku ke bak penampung, maka akan terjadi kontak antara zat besi atau mangan yang ada dalam air dengan oksigen yang ada di udara, sehingga besi atau mangan dapat dioksidasi, yang mana hal tersebut dapat meringankan beban filter mangan zeolitnya. Dengan demikian maka masa pakai (life time) dari filter mangan zeolitnya menjadi lebih lama.

Untuk proses penyaringan, unit filter yang digunakan adalah filter dengan bahan PVC, diameter 12 inc dan tinggi $120 \mathrm{~cm}$. Media yang digunakan adalah pasir silika, mangan zeolit (mangenese greensand, dan karbon aktif. Skema multi media filter yang digunakan dan susunan media dapat dilihat seperti pada Gambar 9, sedangkan konstruksi filternya dapat dilihat pada Gambar 10.

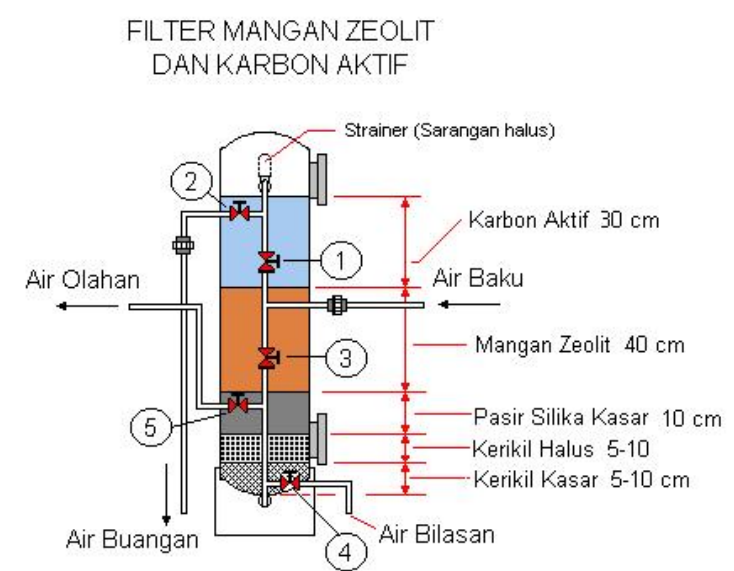

Gambar 9 : Diagram filter multi media dan susunan media penyaring untuk penghilangan zat besi dan mangan di dalam air.

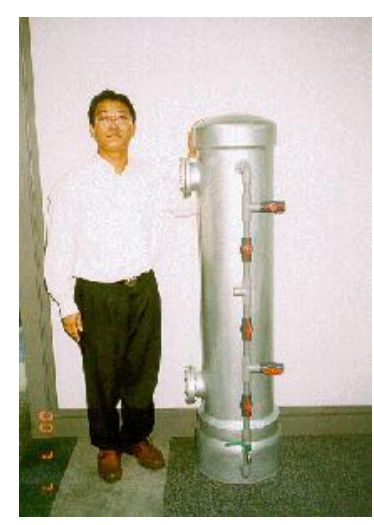

Gambar 10 : Filter multi media untuk menghilangkan zat besi dan mangan di dalam air.

Pengolahan air tanah dengan menggunakan filter mangan zeolit dan filter karbon aktif , serta dilengkapi dengan filter cartridge 5 mikron dan sterilizer Ultra Violet telah dicoba dan menghasilkan air lahan dengan kualitas yang baik. Berdasarkan analisa laboratorium terhadap hasil air olahan untuk parameter yang penting antara lain : kekeruhan, zat besi, mangan, zat organik (angka permanganat), total kesadahan, ammonium $\left(\mathrm{NH}_{4}^{+}\right)$, dan bakteri Coli telah memenuhi stadar baku mutu untuk air minum. Hasil analisa air olahan tersebut dapat dilihat pada Tabel 3.

Dari hasil analisa terhadap air olahan tersebut diatas, jumlah total bakteri Coli nol, sedangkan total plate count masih diatas standar air kemasan. Hal ini air hasil olahan tersebut sudah layak langsung diminum, tetapi tidak disarankan untuk disimpan dalam waktu yang lama.

Tabel 3 : Analisa kualitas air olahan

\begin{tabular}{|l|c|c|c|c|}
\hline Parameter & Satuan & $\begin{array}{c}\text { Air } \\
\text { Olaha } \\
\text { n }\end{array}$ & $\begin{array}{c}\text { Baku } \\
\text { Mutu Air } \\
\text { Minum }{ }^{1)}\end{array}$ & $\begin{array}{c}\text { Baku Mutu } \\
\text { Air } \\
\text { Kemasan }\end{array}$ \\
\hline Kekeruhan & $\mathrm{FTU}$ & nil & 5 & 5 \\
\hline Besi (Fe) & $\mathrm{mg} / \mathrm{l}$ & $<0,04$ & 0,3 & 0,3 \\
\hline $\begin{array}{l}\text { Mangan } \\
(\mathrm{Mn})\end{array}$ & & $<0,02$ & 0,1 & 0,05 \\
\hline $\begin{array}{l}\text { Angka } \\
\text { Permangan } \\
\text { at }\end{array}$ & $\mathrm{mg} / \mathrm{l}$ & nil & 10 & - \\
\hline $\begin{array}{l}\text { Kesadahan } \\
\left(\text { CaCO }_{3)}\right.\end{array}$ & $\mathrm{mg} / \mathrm{l}$ & 1,05 & 500 & - \\
\hline $\begin{array}{l}\text { Ammonium } \\
\left(\mathrm{NH}_{4}{ }^{+}\right)\end{array}$ & $\mathrm{mg} / \mathrm{l}$ & $<0,04$ & - & $\mathrm{ttd}$ \\
\hline $\begin{array}{l}\text { Total } \\
\text { Bakteri Coli }\end{array}$ & $\mathrm{MPN} / \mathrm{ml}$ & nil & 3 & $\mathrm{ttd}$ \\
\hline $\begin{array}{l}\text { Total Plate } \\
\text { Count }\end{array}$ & coloni/ml & $8,210^{4}$ & - & $10^{2}$ \\
\hline
\end{tabular}

\section{Catatan :}

nil : nihil, ttd : tak terdeteksi.

1) Berdasarkan baku mutu air minum PP No. 20 Tahun 1990.

2) FDA Bottled Water Standards.

\subsection{Pilot Plant Proses Khlorinasi- Filtrasi}

Salah satu pilot plant untuk menghilangkan besi dan mangan di dalam air tanah dengan proses khlorinasi-filtrasi (Wong,1984), secara garis besar proses pengolahannya ditunjukkan seperti pada Gambar 11.

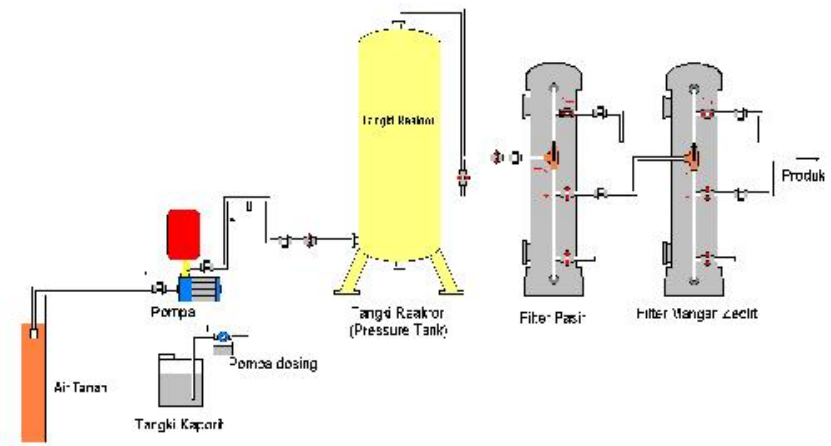

Gambar 11 : Diagram proses penghilangan besi dan mangan di dalam air dengan proses khlorinasi-filtrasi. 
Air dari sumur dipompa dengan menggunakan pompa sambil diinjeksi dengan larutan sodium hipokhlorit untuk mengoksidasi zat besi atau mangan yang ada di dalam air, selanjutnya dialirkan ke static mixer agar larutan sodium hipokhlorit dapat tercampur sempurna dengan air bakunya. Dari static mixer air selanjutnya di alirkan ke tangki reaktor (pressure tank) agar mempunyai waktu yang cukup untuk proses oksidasi sempurna.

Dari tangki reaktor air dialirkan ke saringan pasir cepat bertekanan (rapid pressure filter) untuk menyaring oksida besi atau oksida mangan yang terbentuk di dalam tangki reaktor. Setelah itu dilairkan ke filter mangan zeolit (manganese greensand filter). Filter mangan zeolit berfungsi untuk menghilangkan zat besi atau mangan yang belum sempat teroksidasi oleh kalium permanganat. Untuk menghilangkan polutan mikro misalnya zat organik, deterjen, bau, senyawa phenol, logam berat dan lain-lain proses ini dapat juga dilengkapi dengan filter karbon aktif.

Air hasil olahan selanjutnya dialirkan ke bak penampung air bersih (Tower Tank) atau saluran distribusi. Salah satu contoh konstruksi peralatan proses penghilangan besi dan mangan di dalam air dengan proses khlorinasifiltrasi yang telah terpasang, dengan kapasitas $30 \mathrm{M}^{3}$ per hari dapat dilihat pada Gambar 12 . Spesifikasi teknis peralatan adalah sebagai berikut :

\section{A. Pompa Air Baku}

$\begin{array}{ll}\text { Type } & : \text { jet pump } \\ \text { Power } & : 250 \text { Watt } \\ \text { Pressure } & : 4 \text { Bars (max) } \\ \text { Total Head } & : 40 \mathrm{~m} \\ \text { Jumlah } & : 1 \text { unit }\end{array}$

\section{B. Pompa dosing}

$\begin{array}{ll}\text { Type } & : \text { Chemtech 100/030 } \\ \text { Tekanan } & : 7 \text { Bars } \\ \text { Kapasitas } & : 4.7 \mathrm{It} / \text { hour } \\ \text { Pump head } & : \text { SAN } \\ \text { Diaphragm } & : \text { Hypalon } \\ \text { Jumlah } & : 1 \text { unit }\end{array}$

\section{Tangki Bahan Kimia}

Volume $\quad: 25$ liter
Ukuran $\quad: 50 \mathrm{~cm} \times 25 \mathrm{~cm} \times 10 \mathrm{~cm}$
Material of Contraction : Fiberglass Reinforced
$\begin{aligned} & \text { Plastic (FRP) } \\ & \text { Jumlah }\end{aligned} \quad: 1$ unit

\section{Tangki Reaktor}

$\begin{array}{ll}\text { Kapasitas } & : 0,5-1 \mathrm{M} 3 / \mathrm{jam} \\ \text { Ukuran } & : 63 \mathrm{~cm} \times 120 \mathrm{~cm} \text {, dilengkapi }\end{array}$

$\begin{array}{ll}\text { Material } & \begin{array}{c}\text { dengan penyangga } \\ \text { (FRP) }\end{array} \\ \text { Inlet/Outlet } & : 1 " \\ \text { Tekanan Operasi } & : 4 \text { bar } \\ \text { Jumlah } & : 1 \text { unit } \\ \text { E. Saringan Pasir Cepat (Sand Filter) } \\ \text { Tekanan } & : 3 \text { Bars } \\ \text { Capacity } & : 1.4-1.8 \mathrm{~m} 3 / \text { jam } \\ \text { Ukuran } & : \varnothing 12 \text { inchi } \times 120 \mathrm{~cm} \\ \text { Material } & : \text { FRP } \\ \text { Pipa Inlet / outlet } & : 3 / 4 \text { inch } \\ \text { System } & : \text { Semi automatic backwash } \\ \text { Media Filter } & : \text { Pasir Silika } \\ \text { Media Penahan } & : \text { Gravel } \\ \text { Number } & : 1 \text { unit }\end{array}$

\section{F. Filter mangan Zeolit}

$\begin{array}{ll}\text { Tekanan } & : 3 \text { Bars } \\ \text { Capacity } & : 1.4-1.8 \mathrm{~m} 3 / \text { jam } \\ \text { Ukuran } & : \varnothing 12 \text { inchi x } 120 \mathrm{~cm} \\ \text { Material } & : \text { FRP } \\ \text { Pipa Inlet / outlet } & : 3 \text { inch } \\ \text { System } & : \text { Semi automatic backwash } \\ \text { Media Filter } & : \text { Mangan Zeolit } \\ \text { Media Penahan } & : \text { Gravel } \\ \text { Number } & : 1 \text { unit }\end{array}$

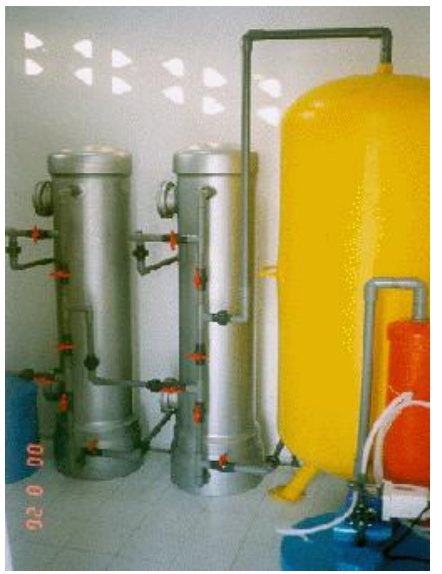

Gambar 12 : konstruksi peralatan proses penghilangan besi dan mangan di dalam air dengan proses khlorinasi-filtrasi.

Proses khlorinasi-filtrasi dapat juga digunakan untuk penghilangan zat besi atau mangan di dalam air slaka rumah tangga. Perbedaan dengan proses skala yang besar adalah pada sistem injeksi senyawa khlorine. Untuk skala yang besar injeksi khlorine atau larutan kaporit umumnya dilakukan dengan menggunakan pompa dosing, sedangkan untuk skala rumah tangga dilakukan dengan sistem injeksi kaporit sederhana menggunakan khlorin tablet. Diagram proses khlorinasi-filtrasi untuk skala rumah tangga dapat dilihat pada Gambar 13, dan skema sistem injeksi khlorine sederhana dapat dilihat pada Gambar 14. Untuk konstruksi Injeksi 
khlorine atau kaporit dan unit filter dapat dilihat pada Gambar 15. Untuk unit filter yang digunakan adalah filter bertekanan dengan menggunakan media pasir, mangan zeolit dan karbon aktif (filter multi media).

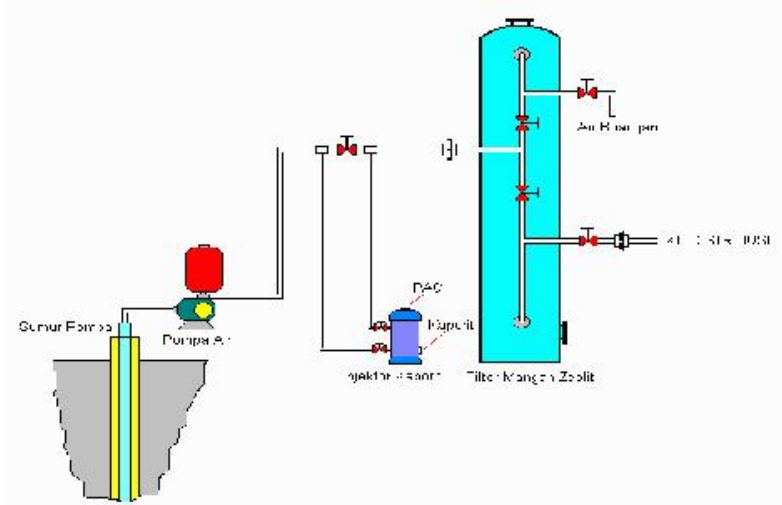

Gambar 13 : Filter mangan zeolit dan karbon aktif skala rumah tangga.

Bentuk serta cara pengoperasian filter secara sederhana ditunjukkan seperti pada gambar 5, sedangkan cara kerja injektor khlorine ditunjukkan pada Gambar 6. Beberapa contoh filter mangan zeolit dan karbon aktif yang dilengkapi dengan injektor khlorine dapat dilihat pada Gambar 7.

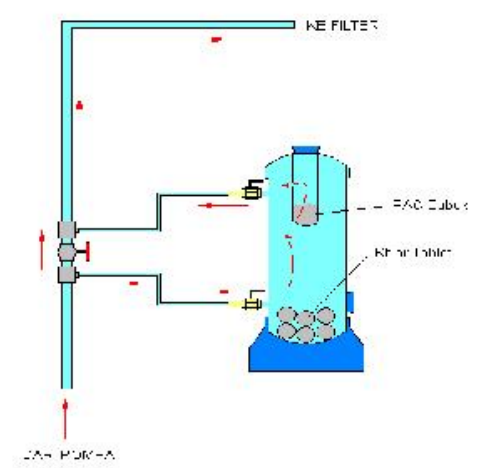

Gambar 14 : Injektor khlorine dan PAC.

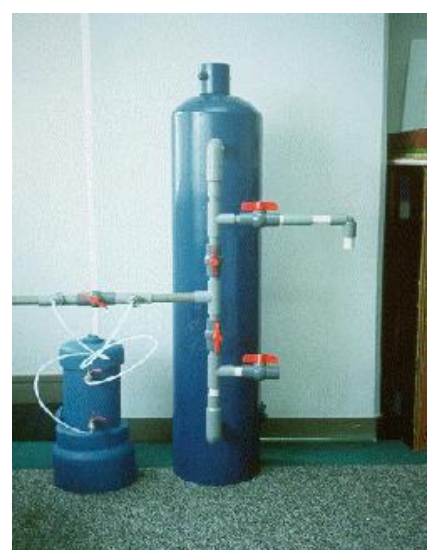

Gambar 15 : Contoh filter mangan zeolit dan karbon aktif serta injektor khlorine.

\subsection{Pilot Plant Proses Kalium Permanganat-Filtrasi dengan Mangan Zeolit}

Pilot plant ini dibangun di daerah pemukiman transmigrasi di Kabupaten Kuala Kapuas, Kalimantan Tengah dengan kapasitas $30 \mathrm{M}^{3}$ per hari. Air yang akan diolah adalah air tanah dengan kandungan zat besi yang cukup tinggi yakni mencapai $10 \mathrm{mg} / \mathrm{l}$ dengan $\mathrm{pH}$ yang rendah yakni sekitar $\mathrm{pH} 4$. Secara fisik pada saat dipompa keluar air terlihat jernih tetapi berbau logam, dan setelah dibiarkan dan kontak dengan udara air akan segera berubah menjadi berwarna coklat kemerahan dan keruh.

Proses yang digunakan yakni kombinasi proses pengaturan $\mathrm{pH}$, proses oksidasi dengan udara, pembubuhan kalium permanganat dan dilanjutkan dengan proses filtrasi. Proses penyaringan terdiri dari tiga tahap yakni penyaringan dengan saringan pasir, kemudian penyaringan dengan filter mangan zeolit (manganese greensand) dan selanjutnya penyaringan dengan media karbon aktif. Diagram proses pengolahannya dapat dilihat seperti pada Gambar 16.

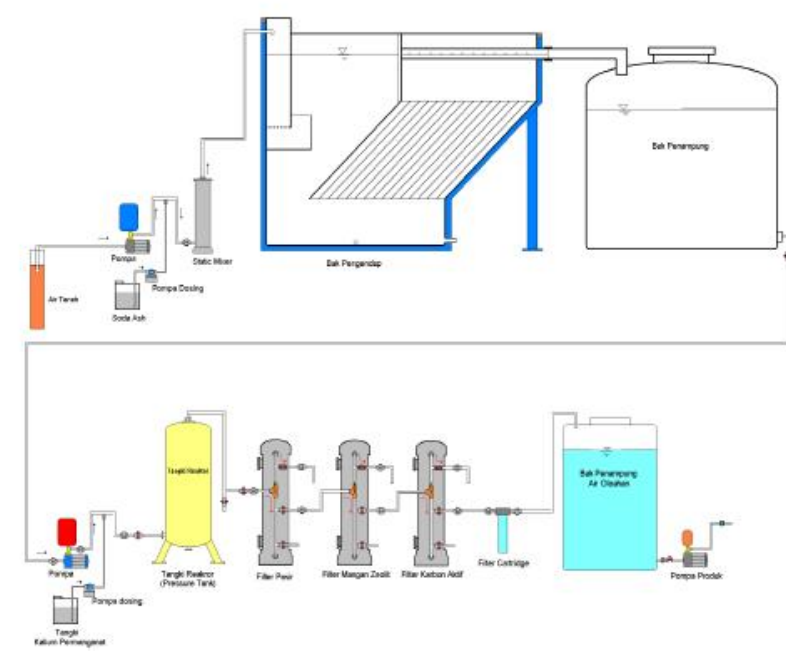

Gambar 16 : Diagram proses penghilangan zat besi dan mangan di dalam air.

Kombinasi proses pengaturan $\mathrm{pH}$, proses oksidasi dengan udara, pembubuhan kalium permanganat dan dilanjutkan dengan proses filtrasi

Air baku yang berasal dari air air tanah dipompa ke tangki pencampur (static mixer) sambil diinjeksi dengan larutan soda ash $\left(\mathrm{NaHCO}_{3}\right)$ untuk menaikkan $\mathrm{pH}$ menjadi sekitar $\mathrm{pH} 7-8$, selanjutnya dialirkan ke bak clarifier atau bak pengendap. Di dalam bak pengendap, dengan adanya penambahan soda ash serta kontak dengan oksigen dari udara, zat besi atau mangan akan dengan cepat teroksidasi menjadi 
oksida besi atau oksida mangan yang tidak larut di dalam air dan akan mengendap di dalam bak pengendap.

Air limpasan dari bak pengendap selanjutnya dialirkan ke bak penampung air baku. Dari bak penampung air baku, air dipompa ke tangki reaktor (tangki bertekanan) sambil diinjeksi dengan larutan kalium permanganat dengan menggunakan pompa dosing, agar zat besi atau mangan yang belum teroksidasi oleh oksigen dari udara dan masih terlarut dalam air dapat dioksidasi lebih sempurna menjadi bentuk senyawa oksida besi atau mangan yang tak larut dalam air.

Zat besi atau mangan di dalam air yang telah teroksidasi dan juga padatan tersuspensi yang berupa partikel halus, selanjutnya di alirkan ke filter pasir (sand filter). Air yang keluar dari saringan pasir selanjutnya dialirkan ke filter mangan zeolit (manganese greensand filter). Dengan adanya filter mangan zeolit ini, zat besi atau mangan yang belum teroksidasi di dalam tangki reaktor dapat dihilangkan sampai konsentrasi $<0,1 \mathrm{mg} / \mathrm{l}$.

Dari filter Mangan Zeolit, air dialirkan ke filter karbon aktif (activated carbon filter) untuk menghilangkan bau atau warna serta polutan mikro. Filter ini mempunyai fungsi untuk menghilangkan senyawa warna dalam air, serta untuk menghilangkan senyawa yang dapat menyebabkan bau. Setelah melalui filter penghilangan warna, air dialirkan ke filter cartridge yang dapat menyaring partikel kotoran sampai ukuran 5 mikron. Dari filter cartridge, selanjutnya, air dialirkan ke bak penampung air olahan dan selanjutnya dipompa ke saluran distribusi. Konstruksi peralatan yang telah terpasang dapat dilihat pada Gambar 17 sampai dengan Gambar 19.

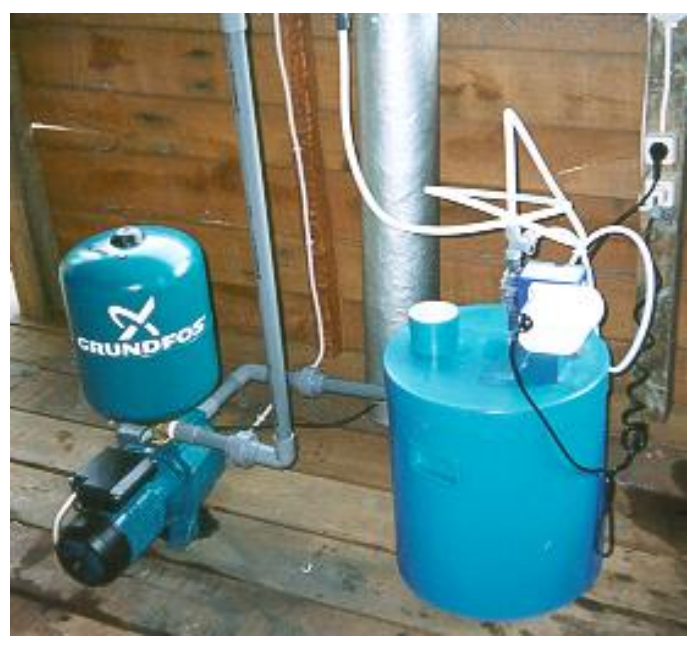

Gambar 17 : Pompa air baku dan sistem injeksi larutan soda ash $\left(\mathrm{NaHCO}_{3}\right)$ untuk menaikkan $\mathrm{pH}$ air.

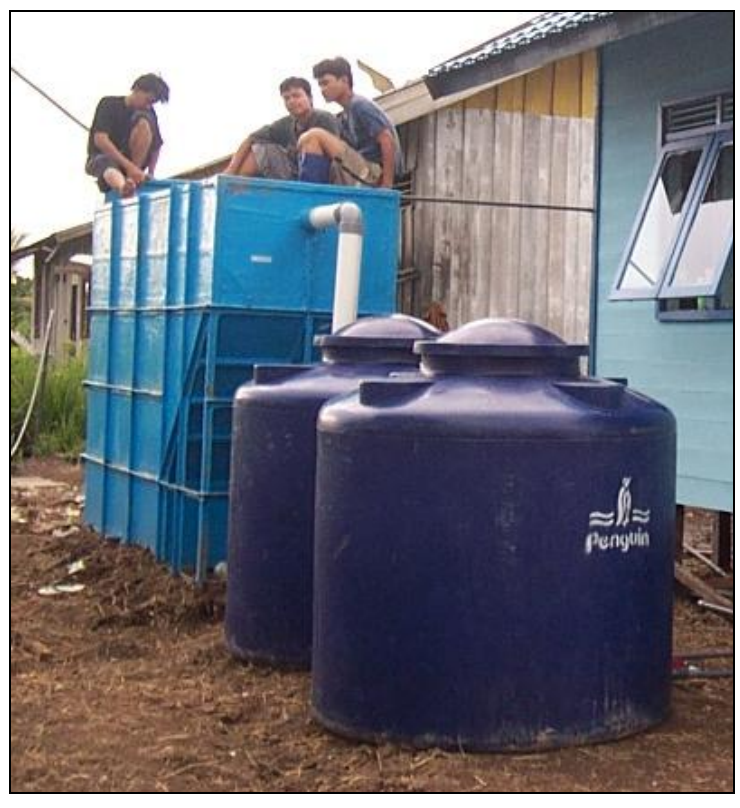

Gambar 18 : Bak pengendap yang berfungsi juga sebagai kontaktor udara kontaktor udara dan bak penampung.

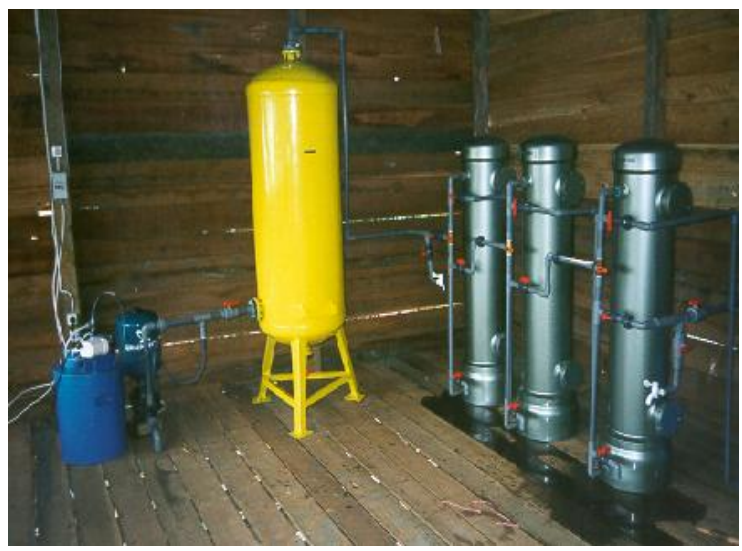

Gambar 19 : Sistem injeksi larutan kalium permanganat, filter pasir, filter mangan zeolit serta filter karbon aktif.

Hasil uji coba pilot plant penghilangan besi dan mangan di dalam air dengan kombinasi proses pengaturan $\mathrm{pH}$, proses oksidasi dengan udara, pembubuhan kalium permanganat dan dilanjutkan dengan proses filtrasi ditunjukkan seperti pada Tabel 4. Dari hasil tersebut dapat dilihat bahwa dengan kombinasi proses tersebut di atas dapat menurunkan kadar zat besi dari $10,06 \mathrm{mg} / \mathrm{l}$ menjadi $0,14 \mathrm{mg} / \mathrm{l}$, dan konsentrasi mangan $(\mathrm{Mn})$ dari 2,94 $\mathrm{mg} / \mathrm{l}$ turun menjadi 0,02 $\mathrm{mg} / \mathrm{l}$. Proses penambahan soda ash $\left(\mathrm{Na}_{2} \mathrm{CO}_{3}\right)$ dilakukan karena air baku mempunyai $\mathrm{pH} \mathrm{5,5}$ sehingga untuk air minum harus dinaikkan menjadi $\mathrm{pH} 6,5-9,0$. 
Tabel 4: Hasil uji coba pilot plant penghilangan besi dan mangan dengan kombinasi proses pembubuhan kalium permanganat dan proses filtrasi.

\begin{tabular}{|l|c|c|}
\hline \multicolumn{1}{|c|}{ Parameter } & Air Baku & Air Olahan \\
\hline $\mathrm{pH}$ & 5,5 & 6,7 \\
\hline Besi (mg/l) & 10,06 & 0,14 \\
\hline Mangan (mg/l) & 2,94 & 0,02 \\
\hline Kekeruhan (NTU) & 60 & 4 \\
\hline Warna (Pt-Co) & 34 & 10 \\
\hline $\begin{array}{l}\text { Kesadahan Total } \\
\text { (mg/l sebagai } \\
\left.\mathrm{CaCO}_{3}\right)\end{array}$ & 64,0 & 60 \\
\hline
\end{tabular}

Catatan :

Lokasi : Dadahup -Kuala Kapuas - Kalteng.

Proses : Kombinasi proses pengaturan $\mathrm{pH}$, proses oksidasi dengan udara, pembubuhan kalium permanganat dan

dilanjutkan dengan proses filtrasi

\section{PENUTUP}

Dari uraian tersebut diatas, beberapa cara oksidasi besi atau mangan yang paling sering digunakan di dalam industri pengolahan air minum antara lain yakni proses aerasi-filtrasi, proses khlorinasi-filtrasi dan proses oksidasi kalium permanganat-Filtrasi dengan mangan zeolit (manganese greensand).

Pemilihan proses tersebut dipilih berdasarkan besarnya konsentrasi zat besi atau mangan serta kondisi air baku yang digunakan, kemudahan proses, serta besarnya biaya pengolahan.

Kombinasi proses aerasi dan proses penyaringan dengan filter yang berisi pasir silika, mangan zeolit dan karbon aktif dapat menurunkan kandungan zat besi dan mangan cukup efefktif, tetapi membutuhkan biaya awal yang lebih besar dan tempat yang lebih besar. Hal ini disebabkan karena oksidasi dengan aerasi udara memerlukan tempat atau bak yang lebih besar sehingga biaya peralatan ralatif lebih besar. Disamping untuk menurunkan kadar besi dan mangan, proses oksidasi zat besi dan mangan dengan cara aerasi filtrasi dapat juga untuk menghilangkan gas karbon dioksida $\left(\mathrm{CO}_{2}\right)$ , gas methan, gas hidrogen sulfida $\left(\mathrm{H}_{2} \mathrm{~S}\right)$ serta dapat menghilangkan bau.

Untuk proses khlorinasi-filtrasi maupun proses kalium permanganat-fitrasi dengan mangan zeolit, peralatan yang digunakan sama yakni sistem pembubuhan bahan kimia, tangki reaktor serta unit filter. $\mathrm{Di}$ dalam proses khlorinasi filtrasi senyawa khlorin yang digunakan adalah gas khlorin atau larutan hipokhlorit. Bahan kimia ini selain merupakan oksidator kuat juga bersifat disinfektan kuat, sehingga selain dapat mengoksidasi zat besi atau mangan juga dapat berfungsi sebagai pembunuh kuman. Tetapi jika pembubuhannya berlebihan maka air olahan akan berbau kaporit yang kurang disenagi masyarakat.

Di dalam proses kalium permanganatfiltrasi dengan managan zeolit bahan kimia yang digunakan yakni larutan kalium permanganat 5 $10 \%$ Kalium permanganat adalah juga merupakan oksidator kuat, berwarna merahkeunguan dan tidak berbau. Jika pembubuhan kaliun permanaganat berlebihan maka air olahan akan berwarna kemerahan.

Pertimbangan utama pemilihan proses khlorinasi-filtrasi atau proses kalium permanganat-filtrasi dengan mangan zeolit adalah pertimbangan harga bahan kimia yang digunakan karena peralatan yang digunakan relatif sama. Untuk harga eceran kaporit saat ini sekitar Rp. 15.000,- (lima belas ribu rupiah) sedangkan harga eceran kalium permanganat sekitar Rp. 50.000 - Rp. 75.000,-

\section{DAFTAR PUSTAKA}

1. Keputusan Menteri Kesehatan Republik Indonesia Nomor 907/MENKES/SK/VII/2002 tanggal 29 Juli 2002 tentang syarat-syarat dan pengawasan kualitas air minum

2. Benefiled, L.D., Judkins, J.F., and Weand, B.L., "Process Chemistry For Water And Waste Treatment", Prentice-Hall, Inc., Englewood, 1982.

3. Fair, G.M., Geyer, J.C., AND Okun, D.A., " Element Of Water Supply And Waste Water Disposal ", Second Edition, John Wiley And Sons, New York, 1971.

4. Hamer, M. J., " Water And Waste water Technology ", Second Edition, John Wiley And Sons, New York, 1986.

5. JICA : Water Supply Engineering Vol. I. Edited by Japan Water Work Association.1990.

6. Peavy, H.S., Rowe, D.R, AND Tchobanoglous, S.G., "Environmental Engineering ", Mc Graw-Hill Book Company, Singapore, 1986.

7. Tatsumi Iwao, "Water Work Engineering (JOSUI KOGAKU) ", Japanese Edition, Tokyo, 1971.

8. Wong, J.M., "Chlorination-Filtration for Iron and Manganese Removal", Journal AWWA Vol.76, NO.1, January 1984. 